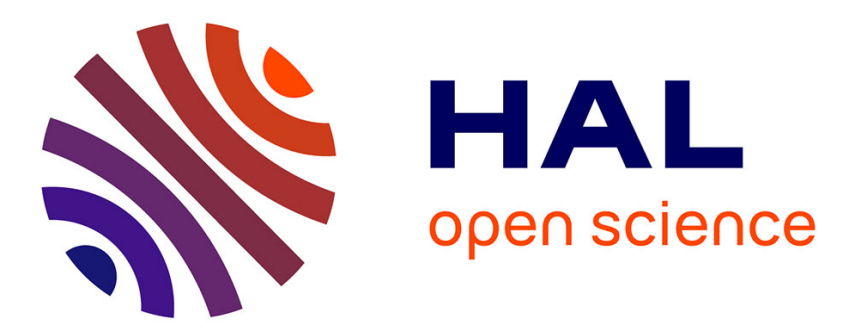

\title{
Sensitivity of isotopically exchangeable phosphate in soil suspensions to the supporting solution
}

\author{
Christian Morel, J. Torrent
}

\section{To cite this version:}

Christian Morel, J. Torrent. Sensitivity of isotopically exchangeable phosphate in soil suspensions to the supporting solution. Soil Science Society of America Journal, 1997, 61 (4), pp.1044-1052. hal-02695061

\section{HAL Id: hal-02695061 https://hal.inrae.fr/hal-02695061}

Submitted on 1 Jun 2020

HAL is a multi-disciplinary open access archive for the deposit and dissemination of scientific research documents, whether they are published or not. The documents may come from teaching and research institutions in France or abroad, or from public or private research centers.
L'archive ouverte pluridisciplinaire HAL, est destinée au dépôt et à la diffusion de documents scientifiques de niveau recherche, publiés ou non, émanant des établissements d'enseignement et de recherche français ou étrangers, des laboratoires publics ou privés. 


\title{
DIVISION S-2-SOIL CHEMISTRY
}

\section{Sensitivity of Isotopically Exchangeable Phosphate in Soil Suspensions to the Supporting Solution}

\author{
C. Morel* and J. Torrent
}

\begin{abstract}
The isotopically exchangeable quantity $\left(E_{f}\right)$ of phosphate measured in 1:10 soil/solution suspensions with deionized water has been identified as the reserve of plant-available phosphate in agricultural soils. We studied the effects of two supporting solutions, $0.01 \mathrm{M} \mathrm{CaCl}$ and deionized water, on $\boldsymbol{E}_{\text {s }}$ values in 27 calcareous agricultural soils. For three soils, $E_{t}$ was also measured after adding increasing phosphate quantities as $\mathrm{KH}_{2} \mathrm{PO}_{4}$, and equilibrating for $24 \mathrm{~h}$, to assess changes in $E_{l}$ with phosphate concentration in solution $\left(C_{\mathrm{P}}\right)$. In unamended and phosphate-enriched soils, $C_{\mathrm{P}}\left(\mathrm{CaCl}_{2}\right)$ was smaller than and related to $C_{\mathrm{P}}\left(\mathrm{H}_{2} \mathrm{O}\right)$. The initial rapidly and the subsequent slowly isotopically exchangeable phosphate were both affected by the use of $\mathrm{CaCl}_{2}$ solution. Since both the rapid and slow isotopically exchangeable phosphate are $C_{\mathrm{P}}$ dependent, the overall effect of $\mathrm{CaCl}_{2}$ solution was analyzed considering two components: (i) a nonspecific effect attributed to the decrease in $C_{\mathrm{P}}$ and (ii) a specific effect attributed to phosphate reactions (i.e., adsorption or precipitation) in calcareous soils. Modifications in $E_{l}$ are the result of both nonspecific and specific effects. The change in $E_{f}$ due to the use of $0.01 \mathrm{M} \mathrm{CaCl}_{2}$ instead of deionized water varies with the soil sample, and can be positive, negative or nil depending on the time of exchange. For instance, after $24 \mathrm{~h}$ of exchange, the ratio $\left\{\left[E_{24 \mathrm{~b}}\left(\mathrm{CaCl}_{2}\right)-E_{24 \mathrm{~b}}\left(\mathrm{H}_{2} \mathrm{O}\right)\right] 100 / E_{24 \mathrm{~b}}\left(\mathrm{H}_{2} \mathrm{O}\right)\right\}$ ranged from -30 to $340 \%$ for the 27 soils. The $0.01 M \mathrm{CaCl}_{2}$ solution thus introduces complex and unpredictable changes in isotopic exchanged phosphate, and its use is not recommended to estimate plantavailable phosphate in soil.
\end{abstract}

$\mathrm{D}$ ESCRIBING PLANT-AVAILABLE PHOSPhate requires the measurement of the so-called Intensity and Quantity factors (Dalal and Hallsworth, 1977; Olsen and Khasawneh, 1980; Ozanne, 1980). The $I$ factor refers to the chemical potential of phosphate in solution, usually estimated by $C_{\mathrm{p}}$. Since the phosphate in solution, which is absorbed by plants via mass flow, represents only 1 to $5 \%$ of the plant phosphate uptake, 95 to $99 \%$ of the phosphate absorbed by plants comes from soil constituents. The $Q$ factor refers to this phosphate reserve that can replenish soil solution phosphate in response to phosphate uptake by roots.

The $Q$ factor within the total phosphate content of agricultural soils has been measured using isotopic labeling procedures applied to soil-plant systems and soil suspensions. With this approach, exchangeable phosphate in soils, i.e., soil phosphate having the same isotopic composition $\left({ }^{32} \mathrm{PO}_{4} /{ }^{31} \mathrm{PO}_{4}\right.$ ratio) as phosphate in soil solution, is labeled with radioisotopes. The isotopic

C. Morel, INRA-Agronomie, BP 81, 33883 Villenave d'Ornon cedex, France; J. Torrent, Departamento de Ciencias y Recursos Agrícolas y Forestales, Universidad de Córdoba, Apdo. 3048, 14080 Córdoba, Spain. Received 19 Feb. 1996. *Corresponding author (morel@ bordeaux.inra.fr).

Published in Soil Sci. Soc. Am. J. 61:1044-1052 (1997) composition of phosphate absorbed by plants after 2 to $3 \mathrm{mo}$ of cropping in greenhouse pot experiments is measured. In parallel, the isotopic composition of phosphate in solution of 1:10 soil/solution suspension with deionized water is measured for similar periods of exchange in laboratory experiments (Fardeau and Jappe, 1976). The similarity between both isotopic compositions of phosphate in plants and phosphate in soil solution has been reported for temperate (Fardeau and Jappe, 1976; Morel and Fardeau, 1991; Morel and Plenchette, 1994) and tropical (Frossard et al., 1994) agricultural soils, and for crop species varying in their mycorrhizal dependency (Morel and Plenchette, 1994). From 95 to $99 \%$ of phosphate absorbed by plants from the soil solid phase has the same isotopic composition as solution phosphate. This is, by definition, the isotopically exchangeable phosphate. Therefore, isotopically exchangeable phosphate is plant-available phosphate for different combinations of agricultural soils and crop species (Morel and Plenchette, 1994).

The $E_{t}$ was initially determined after a defined period of exchange (Russell et al., 1954). However, $E_{t}$ was found to be dependent on the time of exchange. Fardeau $(1981,1993)$ described the increase in $E_{t}$ with time of exchange at a defined $C_{\mathrm{P}}$ level by the following relationship:

$$
E_{t}=E_{1 \mathrm{mn} n^{n}}
$$

where $E_{1 \mathrm{mn}}$ is the isotopically exchangeable phosphate after $1 \mathrm{~min}$ and $n$ is a constant dependent on the soil sample and ranges from 0 to 0.5 . This equation emphasizes the two-step nature of phosphate exchange between the liquid and solid phases of soil. There is an immediate isotopic exchange within the $E_{1 \mathrm{mn}}$ pool followed by a slow time-dependent phase of exchange. The parameter estimates of Eq. [1] are determined for a short period (usually $100 \mathrm{~min}$ ) and can be used successfully to predict $E_{t}$ values for longer periods of exchange (Fardeau and Jappe, 1976; Fardeau, 1981). Equation [1] has been validated in many soil types (Tran et al., 1988; Salcedo et al., 1991; Morel et al., 1994). Functions were recently proposed to take into account the increase in $E_{t}$ when $C_{\mathrm{P}}$ increases (Morel et al., 1994, 1995a,b). The parameter estimates of the $E_{i}$ to $C_{\mathrm{P}}$ relationships were little affected by periods of equilibration ranging from 0.4 to $10 \mathrm{~d}$ (Morel et al., 1995b) or by long-term cultivation practices (Morel et al., 1994). In the above studies, the dependence of $E_{t}$ with time and $C_{\mathrm{P}}$ was studied in $1: 10$ soil/solution suspension with deionized water. However, other supporting solutions (especially $0.01 M$ $\mathrm{CaCl}_{2}$ ) have been used to determine both $C_{\mathrm{P}}$ and $E_{t}$ values (McAuliffe et al., 1948; Russell et al., 1954; Dalal and Hallsworth, 1977; Le Mare, 1982). 
Table 1. Selected properties of the French soils.

\begin{tabular}{|c|c|c|c|c|c|c|c|c|c|c|}
\hline \multirow[b]{2}{*}{ Soil } & \multicolumn{3}{|c|}{ Particle size } & \multirow{2}{*}{$\begin{array}{c}\mathbf{p H} \\
\left(\mathbf{H}_{\mathbf{2}} \mathbf{O}\right)\end{array}$} & \multirow{2}{*}{$\begin{array}{c}\text { Organic } \\
\mathbf{C}\end{array}$} & \multirow{2}{*}{$\begin{array}{c}\mathrm{CaCO}_{3} \\
\text { equivalent }\end{array}$} & \multicolumn{3}{|c|}{ Exchangeable cations } & \multirow[b]{2}{*}{ Total P } \\
\hline & Sand & Silt & Clay & & & & $\mathbf{C a}$ & $\mathbf{M g}$ & $\mathbf{K}$ & \\
\hline & & $-\%-$ & - & & & - & -1 & & & $\mathbf{m g ~ k g ^ { - 1 }}$ \\
\hline 1 & 2 & 77 & 21 & 8.0 & 10.9 & 2 & 3.19 & 0.06 & 0.17 & 610 \\
\hline 2 & 10 & 65 & 25 & 7.9 & 12.7 & 22 & 6.34 & 0.15 & 0.24 & 700 \\
\hline 3 & 10 & 72 & 18 & 8.5 & 8.5 & 42 & nd & 0.24 & 0.22 & nd $\dagger$ \\
\hline
\end{tabular}

$\dagger$ nd = not determined.

The purpose of this study was to evaluate possible effects of using $0.01 M \mathrm{CaCl}_{2}$ on $E_{t}$. The parameters describing the $E_{i}-C_{\mathrm{P}}$ relationship were determined and compared for soil suspensions prepared with either deionized water or $0.01 M \mathrm{CaCl}_{2}$. The comparison was done in calcareous soil samples that provide (with other soils of high base saturation) the conditions under which the use of dilute $\mathrm{CaCl}_{2}$ solution is seemingly appropriate.

\section{MATERIAL AND METHODS}

\section{Soil Samples}

Soil samples were collected from the 0 - to $20-\mathrm{cm}$ layer of three French calcareous loamy Alfisols and from the Ap horizon of 24 Spanish calcareous Inceptisols and Vertisols containing widely different quantities of clay, carbonates, and $\mathrm{Fe}$ oxides. Characteristics of the French soils are shown in Table 1. The Spanish soils were thoroughly described in Solis and Torrent $(1989 \mathrm{a}, \mathrm{b})$. All soil samples were air dried and sieved $(<2 \mathrm{~mm})$ before analysis.

\section{Isotopically Exchangeable Phosphate} at a Defined Soil Solution Phosphate

The quantities of $E_{t}$ were determined in deionized water and $0.01 \mathrm{M} \mathrm{CaCl}_{2}$. After equilibrating $10 \mathrm{~g}$ of soil with $99 \mathrm{~mL}$ of deionized water or $0.01 M \mathrm{CaCl}_{2}$ for $16 \mathrm{~h}, 1 \mathrm{~mL}$ of carrierfree ${ }^{32} \mathrm{P}\left(0.1-1 \mathrm{MBq} \mathrm{mL}{ }^{-1}\right)$ solution $(R)$ was added at time zero and thoroughly mixed with a magnetic stirrer $(\approx 200$ revolutions per minute). About $2 \mathrm{~mL}$ of soil suspension were sampled with a plastic syringe after 1,10 , and $100 \mathrm{~min}$ and filtered through $0.2-\mu \mathrm{m}$ membrane filters. The radioactivity $\left(r_{t}\right)$ remaining in the filtered solution at time $t$ was counted with a liquid scintillation cocktail. The $C_{\mathrm{P}}$ was determined after the last sampling by the ammonium molybdate-ascorbic acid method (John, 1970).

The determination of $E_{l}$ is based on the assumption that in any fraction of $E_{l}$, the isotopic composition of phosphate measured after addition and exchange of carrier-free ${ }^{32} \mathrm{PO}_{4}$ ions is identical to the isotopic composition of phosphate in soil solution. The above hypothesis results in the relationship:

$$
R / E_{t}=r_{t} / 10 C_{\mathrm{P}}
$$

where 10 is the solution/soil ratio. For $t<4 \mathrm{mo}$, the $r_{t} / R$ ratio is related to $t$ by the following equation (Fardeau, 1981, 1993):

$$
r_{t} / R=\left(r_{1 \mathrm{mn}} / R\right) t^{-n}
$$

where $r_{1 \mathrm{mn}} / R$ is the proportion of ${ }^{32} \mathrm{P}$ remaining in soil solution after $1 \mathrm{~min}$ of isotopic exchange and $n$ is an index describing the ${ }^{32} \mathrm{P}$ disappearance from solution with time. Equation [1] is obtained by combining Eq. [2] and [3], where $E_{1 \mathrm{mn}}=10 C_{\mathrm{p}}$ / $\left(r_{1 \mathrm{mn}} / R\right)$.

Table 2. $P$ concentration in solution $\left(C_{\mathrm{p}}\right)$, radioactivity remaining in solution after 1 min $\left(r_{1 \mathrm{mn}} / R\right), n$ exponent $\left(E_{t}=E_{1 \mathrm{mn}} t^{n}\right)$, and

\begin{tabular}{|c|c|c|c|c|c|c|c|c|}
\hline \multirow[b]{2}{*}{ Soil } & \multicolumn{2}{|c|}{$C_{p}$} & \multicolumn{2}{|c|}{$r_{1 \min } / R$} & \multicolumn{2}{|c|}{$n$} & \multicolumn{2}{|c|}{$\boldsymbol{E}_{1 \mathrm{mn}}$} \\
\hline & $\mathbf{H}_{2} \mathbf{O}$ & $\mathrm{CaCl}_{2}$ & $\mathbf{H}_{2} \mathbf{O}$ & $\mathrm{CaCl}_{2}$ & $\mathbf{H}_{2} \mathbf{O}$ & $\mathrm{CaCl}_{2}$ & $\mathbf{H}_{2} \mathbf{O}$ & $\mathbf{C a C l}_{2}$ \\
\hline & \multicolumn{2}{|c|}{$-\mathrm{mg} \mathrm{P} \mathrm{L} \mathrm{L}^{-1}$} & & & & & \multicolumn{2}{|c|}{ mg P kg-1 } \\
\hline \multicolumn{9}{|c|}{ Spanish soils $\dagger$} \\
\hline 1 & 0.020 & 0.011 & 0.14 & 0.07 & 0.34 & 0.34 & 1.4 & 1.6 \\
\hline 2 & 0.042 & 0.015 & 0.14 & 0.05 & 0.30 & 0.31 & 2.9 & 2.9 \\
\hline 3 & 0.035 & 0.007 & 0.11 & 0.03 & 0.31 & 0.32 & 3.2 & 2.2 \\
\hline 4 & 0.048 & 0.016 & 0.20 & 0.08 & 0.30 & 0.30 & 2.4 & 2.1 \\
\hline 5 & 0.053 & 0.021 & 0.20 & 0.10 & 0.31 & 0.32 & 2.7 & 2.2 \\
\hline 6 & 0.065 & 0.021 & 0.22 & 0.10 & 0.30 & $\mathbf{0 . 3 3}$ & 3.0 & 2.2 \\
\hline 7 & 0.031 & 0.012 & 0.25 & 0.10 & 0.32 & 0.33 & 1.3 & 1.2 \\
\hline 8 & 0.40 & 0.10 & 0.41 & 0.21 & 0.20 & 0.23 & 9.3 & 5.0 \\
\hline 9 & 0.029 & 0.012 & 0.13 & 0.05 & 0.28 & 0.31 & 2.3 & 2.7 \\
\hline 10 & 0.121 & 0.029 & 0.19 & 0.06 & 0.21 & 0.26 & 6.5 & 4.5 \\
\hline 11 & 0.026 & 0.013 & 0.16 & 0.08 & 0.34 & 0.39 & 1.6 & 1.6 \\
\hline 12 & 0.021 & 0.009 & 0.11 & 0.05 & 0.35 & 0.38 & 1.9 & 2.0 \\
\hline 13 & 0.017 & 0.011 & 0.16 & 0.07 & 0.42 & 0.40 & 1.0 & 1.7 \\
\hline 14 & 0.007 & 0.009 & 0.22 & 0.10 & 0.33 & 0.36 & 0.3 & 0.9 \\
\hline 15 & 0.037 & 0.22 & 0.29 & 0.12 & 0.28 & 0.32 & 1.3 & 1.8 \\
\hline 16 & 0.035 & 0.015 & 0.16 & 0.08 & 0.36 & 0.37 & 2.1 & 1.9 \\
\hline 17 & 0.004 & 0.009 & 0.07 & 0.05 & 0.37 & 0.38 & 0.6 & 2.3 \\
\hline 18 & 0.063 & 0.020 & 0.29 & 0.08 & 0.21 & 0.25 & 2.2 & 2.6 \\
\hline 20 & 0.035 & 0.018 & 0.20 & 0.08 & 0.34 & 0.35 & 1.8 & 2.2 \\
\hline 21 & 0.079 & 0.040 & 0.33 & 0.11 & 0.21 & 0.25 & 2.4 & 3.6 \\
\hline 22 & 0.013 & 0.012 & 0.14 & 0.11 & 0.36 & 0.25 & 0.9 & 1.8 \\
\hline 23 & 0.005 & 0.006 & 0.10 & 0.04 & 0.36 & 0.36 & 0.5 & 1.6 \\
\hline 24 & 0.041 & 0.020 & 0.23 & 0.09 & 0.25 & 0.28 & 1.8 & 2.3 \\
\hline 25 & 0.016 & 0.013 & 0.21 & 0.08 & 0.34 & 0.35 & 0.8 & 1.7 \\
\hline \multicolumn{9}{|c|}{ French soils } \\
\hline 1 & 0.10 & 0.051 & 0.21 & 0.08 & 0.26 & 0.29 & 4.8 & 6.3 \\
\hline 2 & 0.28 & 0.12 & 0.25 & 0.11 & 0.20 & 0.26 & 11.0 & 11.3 \\
\hline 3 & 0.15 & 0.06 & 0.48 & 0.27 & 0.25 & 0.30 & 3.2 & 2.2 \\
\hline
\end{tabular}
isotopically exchangeable $P$ after $1 \mathrm{~min}\left(E_{1 \mathrm{mn}}\right)$ for all soils and supporting solutions.

$\dagger$ Spanish soil number is the same as in Solis and Torrent $(1989 \mathrm{a}, \mathrm{b})$. 



Fig. 1. Relationship between phosphate concentration in solution $\left(C_{\mathrm{P}}\right),{ }^{32} \mathrm{P}$ radioactivity remaining in solution after $1 \mathrm{~min}\left(r_{\mathrm{lmn}} / R\right)$, isotopically exchangeable phosphate after $1 \mathrm{~min}\left(E_{1 \mathrm{~mm}}\right)$, and the $n$ exponent for soil suspensions in $0.01 M \mathbf{C a C l}_{2}$ or deionized water. The regression lines are: $C_{\mathrm{p}}\left(\mathrm{CaCl}_{2}\right)=0.005+0.31 C_{\mathrm{P}}\left(\mathrm{H}_{2} \mathrm{O}\right)(\mathrm{Fig} .1 \mathrm{a}) ; r_{1 \mathrm{mn}} / R\left(\mathrm{CaCl}_{2}\right)=-0.015+0.50 r_{1 \mathrm{mn}} / R\left(\mathrm{H}_{2} \mathrm{O}\right)(\mathrm{Fig} .1 \mathrm{~b}) ; E_{1 \mathrm{mn}}\left(\mathrm{CaCl}_{2}\right)=0.79+0.73 E_{1 \mathrm{mn}}\left(\mathrm{H}_{2} \mathrm{O}\right)$ (Fig. 1c); and $n\left(\mathrm{CaCl}_{2}\right)=0.08+0.81 n\left(\mathrm{H}_{2} \mathrm{O}\right)$ (Fig. 1d). As Fig. 1a and 1c have log-log scales, plots of linear regressions are nonlinear.

\section{Assessment of the Isotopically Exchangeable Phosphate to Solution Phosphate Relationship}

For the four French soils, six levels of phosphate were added as $\mathrm{KH}_{2} \mathrm{PO}_{4}$ to deionized water and $0.01 M \mathrm{CaCl}_{2}$ suspensions ( $10 \mathrm{~g}$ of soil in $10 \mathrm{~mL}$ of solution) so that phosphate concentrations in soil solution after a given equilibration time ranged from 0.01 to $10 \mathrm{mg} \mathrm{PO}_{4}-\mathrm{P} \mathrm{L}^{-1}$. Phosphate additions up to 300 $\mathrm{mg} \mathrm{PO}_{4}-\mathrm{P} \mathrm{kg}^{-1}$ of soil were required. Each phosphate addition was carried out in duplicate. All suspensions were gently mixed for $5 \mathrm{~min}$ and equilibrated for $24 \mathrm{~h}$ at $22 \pm 3^{\circ} \mathrm{C}$ without shaking to avoid soil particle abrasion. Before determining $C_{\mathrm{P}}, E_{1 \mathrm{mn}}$, and $n$, suspensions were diluted with $90 \mathrm{~mL}$ of deionized water or $0.01 \mathrm{M} \mathrm{CaCl}_{2}$ (to a soil/solution ratio of $1: 10$ ) and gently mixed overnight.

According to Eq. [1], the effect of $C_{\mathrm{P}}$ on phosphate exchange was assessed considering changes in the $E_{1 \mathrm{mn}}$ and $n$ values with $C_{\mathrm{P}}$. The $E_{1 \mathrm{mn}}$ to $C_{\mathrm{P}}$ relationship was described by a Freundlich equation (Morel et al., 1994, 1995a,b):

$$
E_{1 \mathrm{mn}}=\nu C_{\mathrm{P}}^{\mathrm{w}}
$$

where $v$ is the phosphate exchanged after $1 \mathrm{~min}$ at $C_{\mathrm{P}}=1 \mathrm{mg}$ $\mathrm{PO}_{4}-\mathrm{P} \mathrm{L}^{-1}$ and $w$ is a constant describing the nonlinear increase in $E_{\mathrm{lmn}}$ with $C_{\mathrm{P}}$.
The $n$ to $C_{P}$ relationship was described by (Morel et al., 1994, 1995b):

$$
n=p-q \log \left(C_{\mathrm{P}}\right)
$$

where $p$ is the $n$ value at $C_{\mathrm{P}}=1 \mathrm{mg} \mathrm{PO}_{4}-\mathrm{P} \mathrm{L}^{-1}$ and $q$ a constant describing the nonlinear decrease in $n$ with increasing $C_{\mathrm{P}}$.

\section{Statistical Analysis of the Data}

For all soils and supporting solutions, the parameter estimates of Eq. [3], [4], and [5] were obtained using nonlinear, least-squares parameter optimization (Proc NLIN) of SAS software (SAS Institute, 1991). For a given soil, the comparison between the parameter estimates of Eq. [4] and [5] obtained either in $\mathrm{CaCl}_{2}$ solution or deionized water was made using the maximum likelihood test (Huet et al., 1992). The linear regressions were obtained with the regression procedure (Proc. REG) of SAS.

\section{RESULTS}

\section{Soil Solution Phosphate in Unamended Soil}

In the 27 unamended calcareous soils, the phosphate concentration in solution obtained with deionized water 

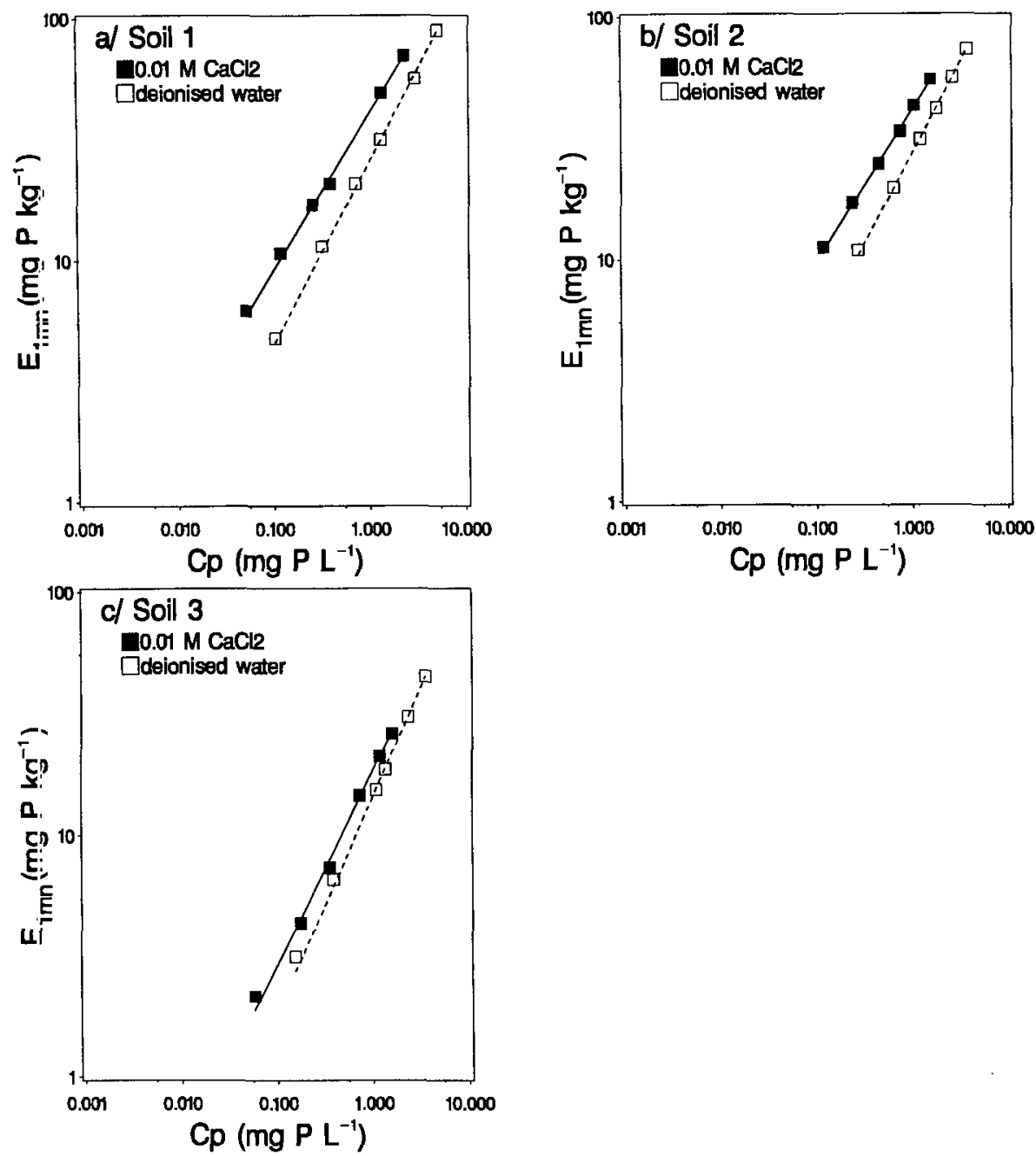

Fig. 2. Isotopically exchangeable phosphate after $1 \mathrm{~min}\left(E_{1 \mathrm{mn}}\right)$ in the three phosphate-amended French soils as a function of phosphate concentration in solution $\left(C_{\mathrm{P}}\right)$ for sail suspensions in $0.01 \mathrm{M} \mathrm{CaCl}$ or deionized water. Lines represent $\mathrm{Eq}$. [4] $\left(E_{\mathrm{lmn}}=v C_{\mathrm{p}}^{\text {p }}\right)$ whose parameter estimates are in Table 3.

$\left[C_{\mathrm{P}}\left(\mathrm{H}_{2} \mathrm{O}\right)\right]$ ranged from 0.004 to 0.379 (mean $=0.065$ ) $\mathrm{mg} \mathrm{PO}-\mathrm{P} \mathrm{L}^{-1}$ (Table 2). Differences in $C_{\mathrm{P}}\left(\mathrm{H}_{2} \mathrm{O}\right)$ values between agricultural soil samples are usual and attributed to soil types and agricultural practices (Fardeau, 1993; Morel et al., 1994, 1995a).

The phosphate concentration in solution in the suspension prepared with $0.01 M \mathrm{CaCl}_{2}\left[C_{\mathrm{P}}\left(\mathrm{CaCl}_{2}\right)\right]$ ranged from 0.006 to 0.120 (mean $=0.026$ ) $\mathrm{mg} \mathrm{PO}_{4}-\mathrm{P} \mathrm{L}^{-1}$ (Table $2)$. The average of the $C_{\mathrm{P}}\left(\mathrm{H}_{2} \mathrm{O}\right) / C_{\mathrm{P}}\left(\mathrm{CaCl}_{2}\right)$ ratio was about 2.5, with maximum and minimum values of 5.0 and 0.4, respectively. A linear relationship $\left[C_{\mathrm{P}}\left(\mathrm{CaCl}_{2}\right)\right.$ $\left.=0.005+0.31 C_{\mathrm{P}}\left(\mathrm{H}_{2} \mathrm{O}\right), R^{2}=0.90\right]$ describes $C_{\mathrm{P}}\left(\mathrm{CaCl}_{2}\right)$ as a function of $C_{\mathrm{P}}\left(\mathrm{H}_{2} \mathrm{O}\right)$ (Fig. 1a).

\section{Immediately Isotopically Exchangeable Phosphare in Calcium Chloride and Deionized Water Suspensions}

The $r_{1 \mathrm{mn}} / R\left(\mathrm{CaCl}_{2}\right.$, were lower than the $r_{1 \mathrm{mn}} / R\left(\mathrm{H}_{2} \mathrm{O}\right)$ values (Table 2). A linear relationship $\left[r_{1 \mathrm{mn}} / R\left(\mathrm{CaCl}_{2}\right)=\right.$ $\left.-0.015+0.50 r_{1 \mathrm{mn}} / R\left(\mathrm{H}_{2} \mathrm{O}\right), R^{2}=0.87\right]$ describes changes in $r_{1 \mathrm{mn}} / R\left(\mathrm{CaCl}_{2}\right)$ witl $r_{1 \mathrm{mn}} / R\left(\mathrm{H}_{2} \mathrm{O}\right)$ values (Fig. $1 \mathrm{~b}$ ).

The $E_{1 \mathrm{mn}}\left(\mathrm{CaCl}_{2}\right)$ values ranged from 1.2 to $11.3 \mathrm{mg}$
$\mathrm{PO}_{4}-\mathrm{P} \mathrm{kg}^{-1}$, with an average value of $2.8 \mathrm{mg} \mathrm{PO}_{4}-\mathrm{P} \mathrm{kg}^{-1}$ (Table 2). The $E_{1 \mathrm{mn}}\left(\mathrm{H}_{2} \mathrm{O}\right)$ values ranged from 0.5 to 9.3 $\mathrm{mg} \mathrm{PO}_{4}-\mathrm{P} \mathrm{kg}^{-1}$, with an average value of $2.7 \mathrm{mg} \mathrm{PO}_{4}-\mathrm{P}$ $\mathrm{kg}^{-1}$. A linear relationship $\left[E_{1 \mathrm{mn}}\left(\mathrm{CaCl}_{2}\right)=0.79+\right.$

Table 3. Regression constants of the $P$ exchanged after 1 min vs. $C_{\mathrm{p}}\left(E_{1 \mathrm{mn}}=v C_{\mathrm{p}}^{*}\right)$ and the time dependence of isotopic exchange vs. $C_{\mathrm{p}}\left[n=p+q \log \left(C_{\mathrm{p}}\right)\right.$ where $n$ is the exponent of $E_{t}=$ $\left.E_{1 m n} t^{n}\right]$ for the three $P$-amended French soils. The $v$ constant is in milligrams $P$ per kilogram. The $w, p$, and $q$ constants are dimensionless.

\begin{tabular}{|c|c|c|c|}
\hline $\begin{array}{l}\text { Soil } \\
\text { reference }\end{array}$ & Solution & $(v, w)$ & $(p, q)$ \\
\hline 1 & $\begin{array}{l}\mathrm{H}_{2} \mathrm{O} \\
\mathrm{CaCl}_{2}\end{array}$ & $\begin{array}{l}(26,0.75) \\
(41,0.65) \\
a^{\dagger}\end{array}$ & $\begin{array}{l}(0.16,0.039) \text { a } \\
(0.16,0.042) \text { a } \\
{[(0.16,0.041)] \doteqdot}\end{array}$ \\
\hline 2 & $\begin{array}{l}\mathrm{H}_{2} \mathrm{O} \\
\mathrm{CaCl}_{2}\end{array}$ & $\begin{array}{l}(27,0.75) \text { a } \\
(42,0.64) \text { b }\end{array}$ & $\begin{array}{l}(0.15,0.036) \\
(0.16,0.041) a \\
{[(0.15,0.037)]}\end{array}$ \\
\hline 3 & $\begin{array}{l}\mathrm{H}_{2} \mathbf{O} \\
\mathrm{CaCl}_{2}\end{array}$ & $\begin{array}{l}(15,0.88) \\
(18,0.80) \\
\text { b }\end{array}$ & $\begin{array}{l}(0.16,0.046) \\
(0.15,0.048) a \\
{[(0.16,0.048)]}\end{array}$ \\
\hline
\end{tabular}

$\dagger$ For each soil, the $(v, w)$ estimates or $(p, q)$ estimates followed by different letters are significantly different $(P<0.05)$.

$\ddagger[(p, q)]$ estimates obtained by regrouping data from both $\mathrm{H}_{2} \mathrm{O}$ and $\mathrm{CaCl}_{2}$ solutions. 

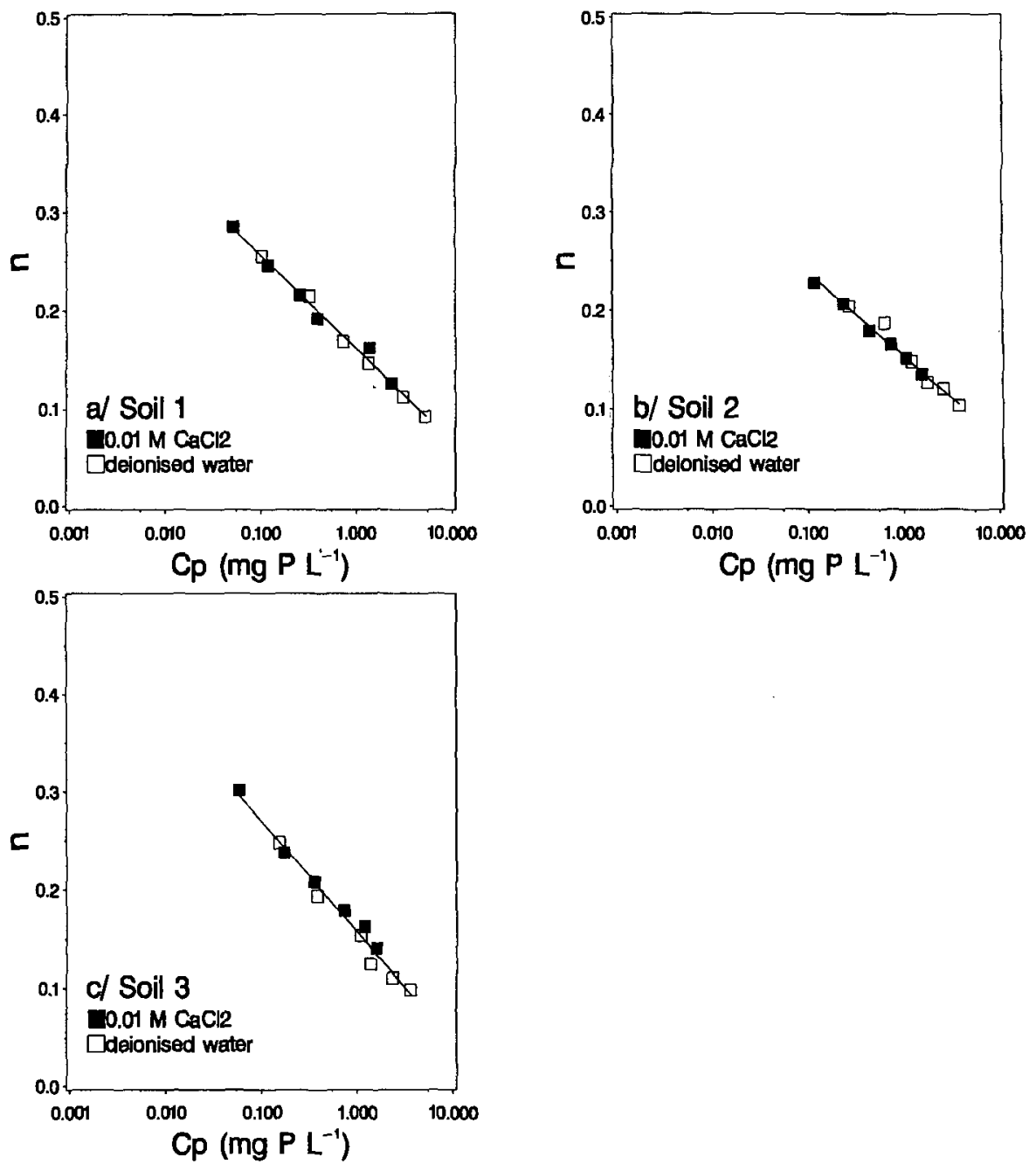

Fig. 3. Relationships between $n\left(E_{t}=E_{\operatorname{lmn}} t^{n}\right)$ and phosphate concentration in solution $\left(C_{\mathrm{p}}\right)$ for soil suspensions of the three phosphate-amended French soils in $0.01 M \mathrm{CaCl}_{2}$ or deionized water. Lines represent $\mathrm{Eq}$. [5] $\left[n=p-q \log \left(C_{\mathrm{P}}\right)\right]$ whose parameter estimates are in Table 3.

$0.73 E_{1 \mathrm{mn}}\left(\mathrm{H}_{2} \mathrm{O}\right), R^{2}=0.78$ ] describes changes in $E_{\mathrm{lmn}}\left(\mathrm{CaCl}_{2}\right)$ with $E_{1 \mathrm{mn}}\left(\mathrm{H}_{2} \mathrm{O}\right)$ values (Fig. 1c).

For a given soil to which increasing phosphate quantities were added, the $E_{1 \mathrm{mn}}\left(\mathrm{CaCl}_{2}\right)$ and $E_{1 \mathrm{mn}}\left(\mathrm{H}_{2} \mathrm{O}\right)$ values increased with increasing soil solution phosphate, irrespective of the supporting solution (Fig. 2). Both changes in $E_{1 \mathrm{mn}}\left(\mathrm{H}_{2} \mathrm{O}\right)$ and $E_{1 \mathrm{mn}}\left(\mathrm{CaCl}_{2}\right)$ values with $C_{\mathrm{P}}\left(\mathrm{H}_{2} \mathrm{O}\right)$ and $C_{\mathrm{P}}\left(\mathrm{CaCl}_{2}\right)$, respectively, are closely described by Eq. [4] for all phosphate-enriched soils (Table $3, R^{2}>0.98$ for all $E_{1 \mathrm{mn}}$ to $C_{\mathrm{P}}$ curves). These results are similar to those obtained for other Canadian and French soils (Morel et al., 1994, 1995a,b).

For each soil, the ( $v, w)$ pair in Eq. [4] was significantly affected by the supporting solution (Table 3 ). The $v$ values were from 27 to $69 \%$ greater, while the $w$ values were from 10 to $20 \%$ smaller in the $\mathrm{CaCl}_{2}$ solution than in deionized water for the three French soils (Table 3 ).

\section{Slowly Isotopically Exchangeable Phosphate in Calcium Chloride and Deionized Water Solution}

For the 27 unamended soils, the $n\left(\mathrm{CaCl}_{2}\right)$ values are higher than $n\left(\mathrm{H}_{2} \mathrm{O}\right.$ ) values (Table 2). A linear relation- ship $\left[n\left(\mathrm{CaCl}_{2}\right)=0.08+0.81 n\left(\mathrm{H}_{2} \mathrm{O}\right), R^{2}=0.91\right] \mathrm{de}-$ scribed the $n\left(\mathrm{CaCl}_{2}\right)$ and $n\left(\mathrm{H}_{2} \mathrm{O}\right)$ values (Fig. 1d).

For a given phosphate-enriched soil, the increase in $C_{\mathrm{P}}$ value induced a decrease in the $n$ value irrespective of supporting electrolytes (Fig. 3). The $n$ to $C_{\mathrm{P}}$ relationships were closely fitted to Eq. [5] for all phosphate-enriched soils and supporting solutions. The $(p, q)$ pair estimate is not significantly different in $\mathrm{CaCl}_{2}$ and deionized water solutions (Table 3 ). Therefore, the increase in $n$ values using the $\mathrm{CaCl}_{2}$ solution compared with deionized water (Fig. 1d) can be solely explained by the lower soil solution phosphate that occurs with $\mathrm{CaCl}_{2}$.

\section{DISCUSSION}

\section{Isotopic Exchange of Phosphate in Soil and Deionized Water}

The reactivity of phosphate in solution with phosphate on the soil solid phase consists of, initially, a fast reaction, followed by a slow continuing reaction (Barrow and Shaw, 1975; Fardeau, 1993). This two-step process is attributed to, among other factors, adsorption onto sites of different affinity for phosphate, diffusion 

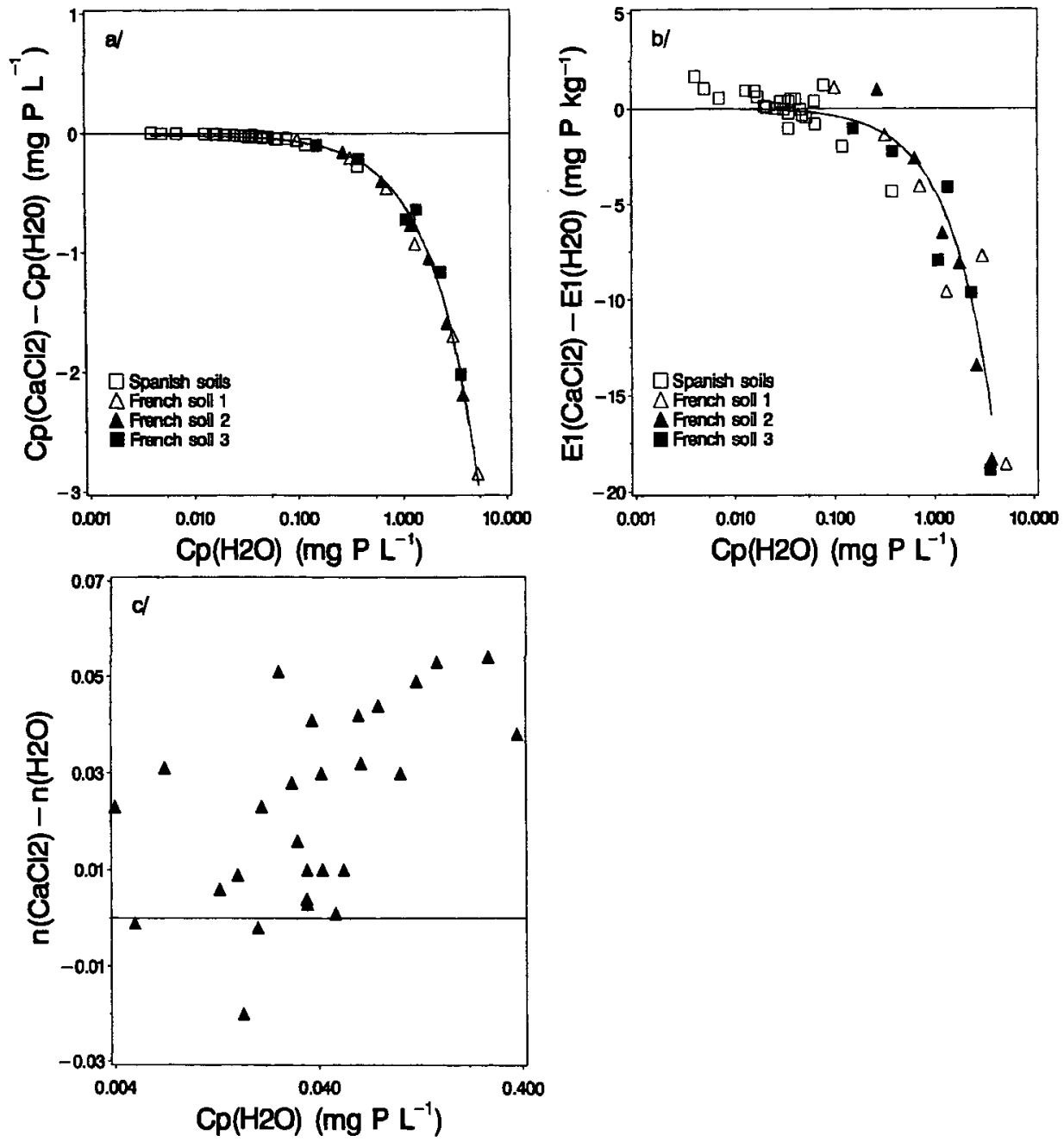

Fig. 4. Variations in the phosphate concentration in solution $\left(C_{\mathrm{p}}\right)$, isotopically exchangeable phosphate after $1 \mathrm{~min}\left(E_{1 \mathrm{mn}}\right)$, and $n\left(E_{t}=E_{1 \mathrm{mn}} t^{n}\right)$ for soil suspensions in $0.01 M \mathrm{CaCl}_{2}$ and deionized water, with respect to $C_{\mathrm{P}}\left(\mathrm{H}_{2} \mathrm{O}\right)$ for unamended soils and phosphate-amended French soils. The value of $C_{\mathrm{P}}\left(\mathrm{H}_{2} \mathrm{O}\right)$ is plotted on a log scale. The linear regressions are: $C_{\mathrm{P}}\left(\mathrm{CaCl}_{2}\right)-C_{\mathrm{P}}\left(\mathrm{H}_{2} \mathrm{O}\right)=-0.01-0.56 C_{\mathrm{P}}\left(\mathrm{H}_{2} \mathrm{O}\right)\left(\mathrm{Fig}^{2}\right.$. 4a); $E_{1 \mathrm{mn}}\left(\mathrm{CaCl}_{2}\right)$ $-E_{1 \mathrm{~mm}}\left(\mathrm{H}_{2} \mathrm{O}\right)=0.06-4.30 C_{\mathrm{P}}\left(\mathrm{H}_{2} \mathrm{O}\right)$ (Fig. 4b).

into soil microaggregates, and various precipitation reactions. The isotopic exchange method mathematically describes each step by taking into account the gross phosphate exchange between solution and solid phase whatever the origin of preexisting phosphate associated with soil constituents and added phosphate. The rapid phosphate exchange corresponds to a dilution of the introduced ${ }^{32} \mathrm{P}$ with phosphate in solution and phosphate associated with soil surfaces that has an immediate ability to exchange with phosphate in solution (Fardeau and Marini, 1968). This phosphate quantity is estimated by the quantity of isotopically exchangeable phosphate in $1 \mathrm{~min}\left(E_{1 \mathrm{mn}}\right)$ in soils of temperate areas (Salcedo et al., 1991). For a given soil, the description of $E_{\mathrm{lmn}}$ to $C_{\mathrm{P}}$ relationship by the Freundlich equation (Morel et al., $1994,1995 \mathrm{a}, \mathrm{b})$ is consistent with the hypothesis of an affinity term decreasing when $E_{1 \mathrm{mn}}$ increases, as reported by Barrow (1978) for phosphate sorption curves.

The slow isotopic phosphate exchange is described by a power function of time (Eq. [1]). The $n$ exponent quantifies the relative importance of the slow exchange with a high $n$ describing greater quantities of slow phos- phate exchange. With increasing $C_{\mathrm{P}}$, phosphate on the soil solid phase increases in addition to phosphate in solution. The decrease in $n$ with increasing $C_{\mathrm{P}}$ (found in this [Fig. 3] as well as other studies: Fardeau, 1993; Morel et al., 1994, 1995b) reflects the decrease in phosphate diffusion to the soil solid phase during slow exchange with increasing phosphate in solution and on the soil solid phase.

\section{Effect of Calcium Chloride Solution on Phosphate Isotopic Exchange}

The use of $\mathrm{CaCl}_{2}$ solution instead of deionized water results in significant changes in $C_{\mathrm{P}}, E_{\mathrm{lmn}}$, and $n$ values (Fig. 1). Since both $E_{1 \mathrm{mn}}$ and $n$ values are $C_{\mathrm{P}}$ dependent (Fig. 2 and 3), the assessment of the specific effect of the $\mathrm{CaCl}_{2}$ solution on $E_{1 \mathrm{mn}}$ and $n$ requires that effects of a decrease in $C_{\mathrm{P}}$ on $E_{1 \mathrm{mn}}$ and $n$ values be distinguished from the interactions. This was done by (i) studying changes in the $C_{\mathrm{P}}\left(\mathrm{CaCl}_{2}\right)-C_{\mathrm{P}}\left(\mathrm{H}_{2} \mathrm{O}\right), E_{1 \mathrm{mn}}\left(\mathrm{CaCl}_{2}\right)-$ $E_{1 \mathrm{mn}}\left(\mathrm{H}_{2} \mathrm{O}\right)$, and $n\left(\mathrm{CaCl}_{2}\right)-n\left(\mathrm{H}_{2} \mathrm{O}\right)$ values with the $C_{\mathrm{P}}\left(\mathrm{H}_{2} \mathrm{O}\right)$ values (Fig. 4), and also (ii) comparing the 


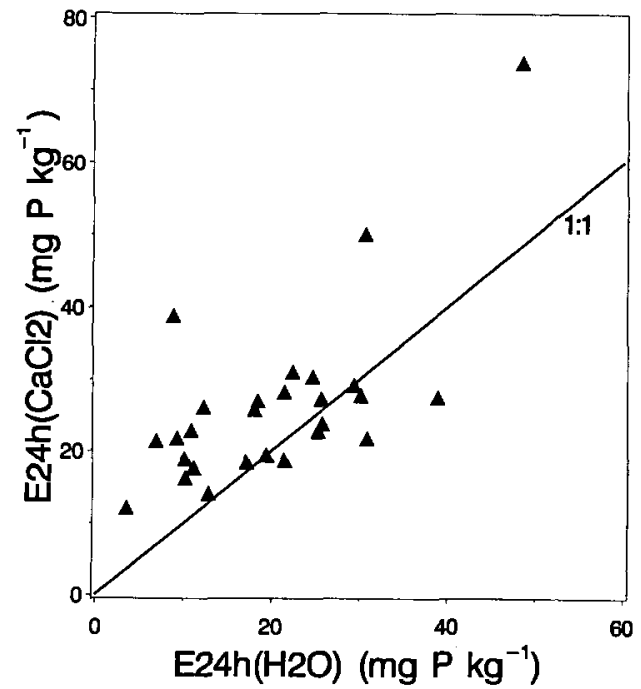

Fig. 5. Relationship between the isotopically exchangeable phosphate after $24 \mathrm{~h}\left(E_{24 h}\right)$ for soil suspensions in $0.01 \mathrm{M} \mathrm{CaCl}_{2}$ and deionized water for the 27 unamended soils. The $E_{24 \mathrm{~h}}$ values were calculated from Eq. [5] and parameters in Table 2. Line shown is 1:1.
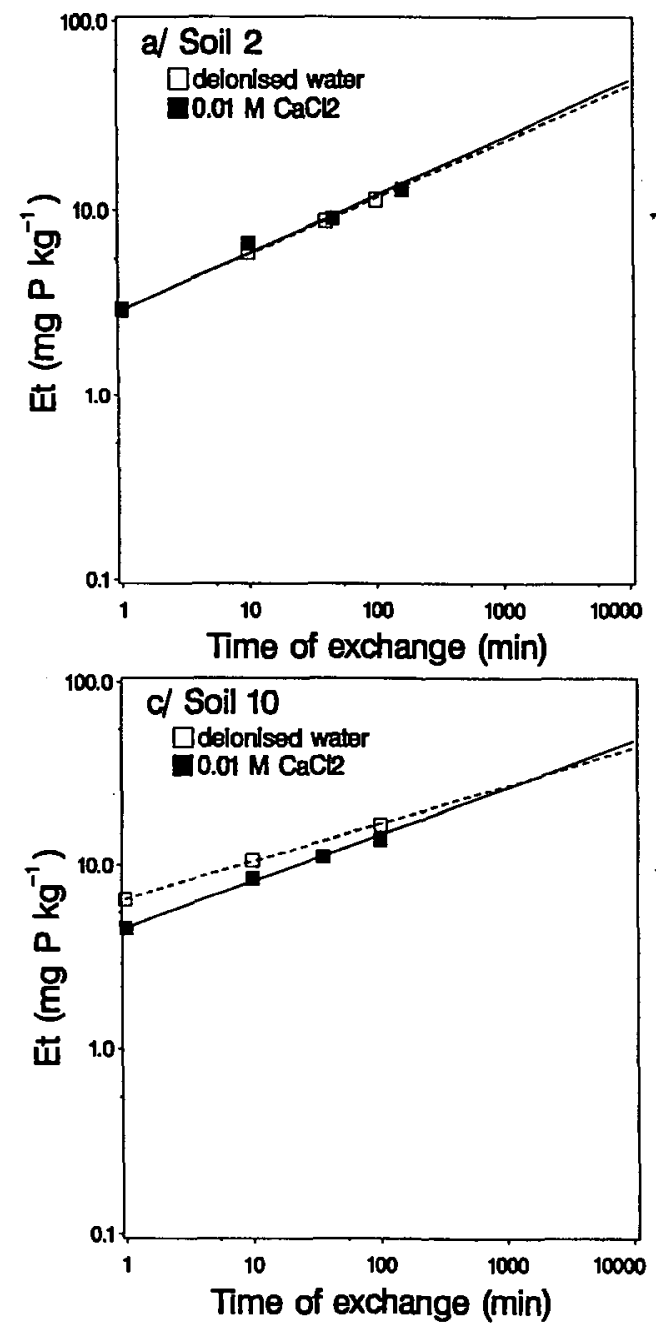

$E_{1 \mathrm{mn}}-C_{\mathrm{P}}$ and $n-C_{\mathrm{P}}$ relationships obtained for the two supporting solutions in phosphate-enriched soils (Fig. 2 and 3).

The effect of the $\mathrm{CaCl}_{2}$ solution on $C_{\mathrm{P}}$ is fully explained as a function of the $C_{\mathrm{P}}\left(\mathrm{H}_{2} \mathrm{O}\right)$ values (Fig. 4a) since the $C_{\mathrm{P}}\left(\mathrm{CaCl}_{2}\right)-C_{\mathrm{P}}\left(\mathrm{H}_{2} \mathrm{O}\right)$ values closely fitted $\left(R^{2}\right.$ $=0.99)$ by a linear regression $\left[C_{\mathrm{P}}\left(\mathrm{CaCl}_{2}\right)-C_{\mathrm{P}}\left(\mathrm{H}_{2} \mathrm{O}\right)=\right.$ $\left.-0.01-0.56 C_{\mathrm{P}}\left(\mathrm{H}_{2} \mathrm{O}\right)\right]$ for all unamended and phosphate-enriched soils (42 samples). The greater $C_{\mathrm{P}}\left(\mathrm{H}_{2} \mathrm{O}\right)$, the greater the decrease in $C_{\mathrm{P}}\left(\mathrm{CaCl}_{2}\right)$. This result is explained by an increase in phosphate sorption in $0.01 \mathrm{M}$ $\mathrm{CaCl}_{2}$ (Ryden and Syers, 1975; Helyar et al., 1976).

The effect of the $0.01 M \mathrm{CaCl}_{2}$ solution on $E_{1 \mathrm{mn}}$ (Fig. $4 \mathrm{~b})$ is explained $\left(R^{2}=0.90\right)$ by $C_{\mathrm{P}}$ since $E_{1 \mathrm{mn}}\left(\mathrm{CaCl}_{2}\right)-$ $E_{1 \mathrm{mn}}\left(\mathrm{H}_{2} \mathrm{O}\right)$ related to $C_{\mathrm{P}}\left(\mathrm{H}_{2} \mathrm{O}\right)$ values by a linear regression $\left[E_{1 \mathrm{mn}}\left(\mathrm{CaCl}_{2}\right)-E_{1 \mathrm{mn}}\left(\mathrm{H}_{2} \mathrm{O}\right)=0.06-4.30 C_{\mathrm{P}}\left(\mathrm{H}_{2} \mathrm{O}\right)\right.$, $n=42]$ for unamended and phosphate-enriched soils (Fig. 4b). At low $C_{\mathrm{P}}\left(\mathrm{H}_{2} \mathrm{O}\right)$ values, the variation is positive and becomes increasingly negative when $C_{\mathrm{P}}\left(\mathrm{H}_{2} \mathrm{O}\right)$ values increase. These results might be explained by the phosphate reactions occurring in calcareous soils. At low $C_{\mathrm{P}}\left(\mathrm{H}_{2} \mathrm{O}\right)$ values, the reaction of phosphate in solution with $\mathrm{CaCO}_{3}$ is likely to be orthophosphate adsorp-


Fig. 6. Time-dependent isotopically exchangeable phosphate $\left(E_{t}=E_{1 \mathrm{~m}} t^{n}\right)$ for four soil suspensions in deionized water or $0.01 M$ CaCl ${ }_{2}$. The four soils are the Spanish soils referenced as $2,8,10$, and 17 in Solis and Torrent $\left(1989\right.$ a,b) and represent the variability of the $E_{t}$ to $t$ relationships found in the 27 unamended soils. 
tion. Higher $\mathrm{Ca}$ activity in solution decreases the negative potential of the $\mathrm{Ca}-\mathrm{P}$ surfaces and enhances surface phosphate adsorption (Ryden and Syers, 1975). At higher $C_{\mathrm{P}}\left(\mathrm{H}_{2} \mathrm{O}\right)$ values, the $0.01 M \mathrm{CaCl}_{2}$ solution may promote the formation of $\mathrm{Ca}$-phosphate-carbonate complexes or precipitation of Ca phosphates on the surface of $\mathrm{CaCO}_{3}$ (Freeman and Rowell, 1981; Avnimelech, 1980; Salingar and Kochva, 1994) before measuring isotopic exchange. These precipitates do not exchange as readily as phosphate solid phases in deionized water. As a result, the rapid phosphate exchange decreases (the $E_{1 \mathrm{mn}}$ value decreases) in $\mathrm{CaCl}_{2}$, whereas the slow phosphate exchange increases (the $n$ value increases).

The $n\left(\mathrm{CaCl}_{2}\right)-n\left(\mathrm{H}_{2} \mathrm{O}\right)$ values were not explained by $C_{\mathrm{P}}\left(\mathrm{H}_{2} \mathrm{O}\right)$ values (Fig. $4 \mathrm{c}$ ). The same conclusion is obtained by comparing, for a defined soil, the $n-C_{\mathrm{P}}$ relationship in the two supporting solutions (Fig. 3). The increase in $n\left(\mathrm{CaCl}_{2}\right)$ compared with $n\left(\mathrm{H}_{2} \mathrm{O}\right)$ is only due to the decrease in $C_{\mathrm{P}}\left(\mathrm{CaCl}_{2}\right)$ compared with $C_{\mathrm{P}}\left(\mathrm{H}_{2} \mathrm{O}\right)$ since parameter estimates of both $n-C_{\mathrm{P}}$ relationships are not significantly different. Therefore, the $\mathrm{CaCl}_{2}$ solution relative to the deionized water has no specific effect on the slow exchange process as described by the $n$ to $C_{\mathrm{P}}$ curve. The variability in the $n\left(\mathrm{CaCl}_{2}\right)$ $-n\left(\mathrm{H}_{2} \mathrm{O}\right)$ value is likely to be influenced by various soil properties.

\section{Comparison between Isotopically Exchangeable Phosphate in Calcium Chloride and Deionized Water: Agronomic Significance}

Although Eq. [1] is determined for $100 \mathrm{~min}$, it successfully predicts $E_{t}$ values up to 3 mo of exchange (Fardeau, 1981; Fardeau and Jappe, 1976). For the 27 unamended soils, the relationship between isotopically exchangeable phosphate after $24 \mathrm{~h}$ (which is a very common exchange time in the literature) in $\mathrm{CaCl}_{2}\left[E_{24 \mathrm{~h}}\left(\mathrm{CaCl}_{2}\right)\right]$ and deionized water $\left[E_{24 \mathrm{~h}}\left(\mathrm{H}_{2} \mathrm{O}\right)\right]$ is shown in Fig. 5. The ratio $E_{24 \mathrm{~h}}\left(\mathrm{CaCl}_{2}\right)-E_{24 \mathrm{~h}}\left(\mathrm{H}_{2} \mathrm{O}\right)$ to $E_{24 \mathrm{~h}}\left(\mathrm{H}_{2} \mathrm{O}\right)$ ranged from -30 to $343 \%$.

Differences in $E_{24 \mathrm{~h}}$ induced by the supporting solution underline the need to adopt a standardized method for measuring isotopically exchangeable phosphate and caution against direct comparisons between data obtained by different researchers. Furthermore, differences in $E_{t}$ values obtained using the two supporting solutions also depend on the period of exchange (Fig. 6). For instance, if the rate of change of $E_{t}$ is extrapolated over 10000 min $(\approx 1 \mathrm{wk})$, the difference between $E_{t}\left(\mathrm{CaCl}_{2}\right)$ and $E_{t}\left(\mathrm{H}_{2} \mathrm{O}\right)$ varies with time. The plots of $E_{t}\left(\mathrm{CaCl}_{2}\right)$ and $E_{t}\left(\mathrm{H}_{2} \mathrm{O}\right)$ with time for four Spanish soils, selected to be representative of the variability found in all soils, show that the $E_{i}\left(\mathrm{CaCl}_{2}\right)-E_{i}\left(\mathrm{H}_{2} \mathrm{O}\right)$ value can be negative, positive, or nil depending on the time of exchange (Fig. 6). It seems, consequently, there is no way to easily relate results obtained with the different supporting solutions since the $\mathrm{CaCl}_{2}$ solution affects the isotopic phosphate exchange process by: (i) decreasing soil solution phosphate [the greater the $C_{\mathrm{P}}\left(\mathrm{H}_{2} \mathrm{O}\right)$ value, the greater the decrease is]; (ii) decreasing the rapid exchange of phosphate between liquid and solid phases [also, the greater the $C_{\mathrm{P}}\left(\mathrm{H}_{2} \mathrm{O}\right)$ value, the greater the decrease is]; and (iii) increasing the importance of slow relative to rapid phosphate exchange.

Two of the above effects are mainly controlled by the phosphate concentration in soil solution, which is by nature highly variable since it depends on soil types, pedogenetic evolution, and agricultural practices. The result of these effects and their interactions is a wide and unpredictable variability among soils for $E_{t}$ obtained either in $0.01 \mathrm{M} \mathrm{CaCl}_{2}$ or deionized water.

Finally, these results have significant agronomic implications. The isotopic phosphate exchange method using deionized water gives an estimate of the reserve of plant-available phosphate in soils (Fardeau and Jappe, 1976; Morel and Fardeau, 1991; Morel and Plenchette, 1994; Frossard et al., 1994). This study shows that the $0.01 \mathrm{M} \mathrm{CaCl}_{2}$ solution modifies directly and indirectly (through soil solution phosphate) both rapid and slow phosphate exchange. The resulting overall effect varies with soil types and agricultural practices, obscuring the significance of $E_{t}$ measured in deionized water. To adequately estimate the reserve of plant-available phosphate, use of $0.01 M \mathrm{CaCl}_{2}$ solution should be avoided.

\section{ACKNOWLEDGMENTS}

This research was partly supported by the Spanish C.I.C.Y.T., Project AGR91-0436. We thank Dr. J.C. Fardeau (CEA), Prof. E. Frossard (ETH-Zürich), and Dr. A. Oberson (ETH-Zürich) for their helpful suggestions and Ms. Blanca Castro and Ms. Josette Gonthier for obtaining the isotopic exchange data.

\section{REFERENCES}

Avnimelech, Y. 1980. Calcium-carbonate-phosphate surface complex in calcareous systems. Nature (London) 288:255-257.

Barrow, N.J. 1978. The description of phosphate adsorption relationships. J. Soil Sci. 29:447-462.

Barrow, N.J., and T.C. Shaw. 1975. The slow reactions between soil and anions: 2 . Effect of time and temperature on the decrease in phosphate concentration in the soil solution. Soil Sci. 119:167-177.

Dalal, R.C., and E.G. Hallsworth. 1977. Measurement of isotopic exchangeable soil phosphorus and interrelationship among parameters of quantity, intensity, and capacity factors. Soil Sci. Soc. Am. J. 41:81-86.

Fardeau, J.C. 1981. Cinétiques de dilution isotopique et phosphore assimilable des sols. Thèse de Doctorat d'Etat. Université Pierre et Marie Curie, Paris VI

Fardeau, J.C. 1993. Available soil phosphate: A mamellary system. Agronomie 13:317-331.

Fardeau, J.C., and J. Jappe. 1976. Nouvelle méthode de détermination du phosphore assimilable par les plantes dans les systèmes sol:solution. C.R. Acad. Sci. Sér. 3 300(8):371-376.

Fardeau, J.C., and P. Marini. 1968. Détermination par échange isotopique en retour, du compartiment des ions phosphate les plus mobiles du sol. C.R. Acad. Sci. 267D:427-430.

Freeman, J.S., and D.L. Rowell. 1981. The adsorption and precipitation of phosphate onto calcite. J. Soil Sci. 32:75-84.

Frossard, E., J.C. Fardeau, M. Brossard, and J.L. Morel. 1994. Soil isotopically exchangeable phosphate: A comparison between $E$ and $L$ values. Soil Sci. Soc. Am. J. 58:846-851.

Helyar, K.R., D.N. Munns, and R.G. Burau. 1976. Adsorption of phosphate by gibbsite. I. effects of neutral chloride salts of calcium, magnesium, sodium, and potassium. J. Soil Sci. 27:307-314.

Huet, S., E. Jolivet, and A. Messéan. 1992. La régression non-linéaire. Méthodes et applications en biologie. Edit. INRA, Paris.

John, M.K. 1970. Colorimetric determination of phosphate in soil and plant material with ascorbic acid. Soil Sci. 109:214-220. 
Le Mare, P.H. 1982. Sorption of isotopically exchangeable and nonexchangeable phosphate by some soils of Colombia and Brazil, and comparisons with soils of southern Nigeria. J. Soil Sci. 33:691-707.

McAuliffe, C.D., N. Hall, L.A. Dean, and S.B. Hendricks. 1948. Exchange reactions between phosphate and soils: Hydroxylic surfaces of soil minerals. Soil Sci. Soc. Am. Proc. 12:119-123.

Morel, C., J. Blaskiewitz, and J.C. Fardeau. 1995a. Phosphorus supply to plants by soils with variable $P$ exchange. Soil Sci. 160:423-430.

Morel, C., and J.C. Fardeau. 1991. Phosphate bioavailability of fertilizers: A predictive laboratory method for its evaluation. Fert. Res. 24:115-122.

Morel, C., A. Oberson, and H. Tiessen. 1995b. An equilibration timeindependent method to assess the reactivity of $P$ ions in soils. p. 667-670. In Int. Symp. nuclear and related techniques in soil/ plant studies on sustainable agriculture and environmental preservation, Vienna. 17-21 Oct. 1995. IAEA, Vienna.

Morel, C., and C. Plenchette. 1994. Is the isotopically exchangeable phosphate of a loamy soil the available $P$ to growing plant? Plant Soil 158:287-297.

Morel, C., H. Tiessen, J. Moir, and J.W.B. Stewart. 1994. Phosphate transformations and availability under cropping and fertilization assessed by isotopic exchange. Soil Sci. Soc. Am. J. 58:1439-1445.

Olsen, S.R., and F.E. Khasawneh. 1980. Use and limitations of physicochemical criteria for assessing the status of phosphorus in soils. p. 361-410. In F.E. Khasawneh et al. (ed.). The role of phosphorus in agriculture. ASA, CSSA, and SSSA, Madison, WI.
Ozanne,P.G. 1980. Phosphate nutrition of plants - A general treatise. p. 559-589. $\ln$ F.E. Khasawneh et al. (ed.). The role of phosphorus in agriculture. ASA, CSSA, and SSSA, Madison, WI.

Russell, R.S., J.B. Rickson, and S.N. Adams. 1954. Isotopic equilibria between $P$ in soil and their significance in the assessment of fertility by tracer methods. J. Soil Sci. 5:85-105.

Ryden, J.C., and J.K. Syers, 1975. Rationalization of cation and ionic strength effects on phosphate sorption by soils. J. Soil Sci. 26: 395-406.

Salcedo, I.H., F. Bertino, and E.V.S.B. Sampaio. 1991. Reactivity of phosphate in northeastern Brazilian soils assessed by isotopic dilution. Soil Sci. Soc. Am. J. 55:140-145.

Salingar, Y., and M. Kochva. 1994. Solute partitioning in a calcium carbonate-phosphoric acid-water system. Soil Sci. Soc. Am. J. 58:1628-1632.

SAS Institute. 1991. SAS/STAT and SAS/GRAPH guides for personal computer. Version 6.07 ed. SAS Inst., Cary, NC.

Solis, P., and J. Torrent. 1989a. Phosphorus sorption by calcareous Vertisols and Inceptisols of Spain. Soil Sci. Soc. Am. J. 53:456-459.

Solis, P., and J. Torrent. 1989b. Phosphate fractions in calcareous Vertisols and Inceptisols of Spain. Soil Sci. Soc. Am. J. 53:462-466.

Tran, T.S., J.C. Fardeau, and M. Giroux. 1988. Effects of soil properties on plant-available phosphate determined by the isotopic dilution phosphate-32 method. Soil Sci. Soc. Am. J. 52:85-105 